\title{
PARIWISATA SEKSUAL ANAK : UPAYA PERLINDUNGAN ANAK BERKAITAN DENGAN SEX CHILD TOURISM
}

\author{
Oleh:
}

\author{
Izzah Amila Faisal ${ }^{1}$
}

\begin{abstract}
Tourism is the one of the main revenue in Indonesia. A large of number tourists comes to Indonesia every day with the different country, culture and aim. Base on our international visitor that come from different country, they bring together with their culture when visit Indonesia. Therefore tourism has the positive and negative impact for our culture. As Indo people we have to keep save our basic identity from the acculturation. But in other hand tourism have some negative effect. Child Sex tourism is the issue of this paper and become one of the phenomena that occur in Indonesian tourism. Even though Indonesia have the national and international regulation that protect child from sex exploitation, but in the real life still find the same issue regarding child sex tourism. The purpose of this research is to find and identify the factor that be the main cause of child sex tourism to be able to conclude the efforts of legal protection rights of children and also against sex child tourism practice and protect the from any kind of sexual crime practice. As we know that the children are our future generation that must be protected all of their rights. Law enforcement officers together with the government need more improvement efforts to against sexual crime practice specialy that happen with the children in Indonesia.
\end{abstract}

Keywords: Child sex tourism, sex exploitation

\section{PENDAHULUAN}

\subsection{Latar Belakang}

Pariwisata merupakan salah satu penyumbang devisa negara terbesar yang berasal dari Bali dan merupakan sektor pendapatan utama dan andalan negara Indonesia. ${ }^{2}$ Namun apabila pariwisata tidak ditangani dan dijalankan dengan baik maka akan berdampak negatif seperti kerusakan terhadap nilai dari suatu seni dan budaya,

\footnotetext{
Mahasiswi Magister Ilmu Hukum Universitas Udayana, Denpasar, Bali, Alamat Jalan Pulau Seram Gang Tarakan Buntu No. 3 Denpasar, e-mail: miela_zhaa@yahoo.com

Iriandika Prabhata, 2015, Meningkatkan Pariwisata Bali Melalui Kepastian Penegakan Hukum atas Pelanggaran Kawasan Tanpa Rokok Dalam Peraturan Daerah Propinsi Bali No. 10 Tahun 2011, Jurnal Magister Hukum Udayana, Vol.8 No.1 Tahun 2015, Magister Hukum Universitas Udayana, Denpasar, hlm.3.
}

hancurnya ekosistem serta pelanggaran terhadap norma agama, adat istiadat, kesusilaan dan hak asasi manusia pada suatu daerah destinasi wisata.

Berwisata merupakan hak setiap orang dan hak asasi setiap manusia yang telah diakui oleh hukum nasional dan juga internasional. ${ }^{3}$ Namun hak tersebut harus dilakukan untuk kegiatan positif. Namun belakangan ini hak berwisata sudah mengganggu eksistensi hak anak, karena sudah marak terjadinya pariwisata yang berdampak negatif bagi tumbuh kemabang anak, yaitu pariwisata seksual anak. Hak anak merupakan salah

Eva Laheri, 2015, Tanggung Jawab Negara Terhadap Kerugian Wisatawan Berkaitan Dengan Pelanggaran Hak Berwisata Sebagai Bagian Dari Hak Asasi Manusi, Jurnal Magister Hukum Udayana Vol.8 No.1 Tahun 2015, Magister Hukum Universitas Udayana, Denpasar, hlm.3. 
satu aspek yang harus diperhatikan dalam perkembangan pariwisata karena dalam industri pariwisata sangat besar potensi yang ditimbulkan untuk terjadinya kejahatan seksual pada anak. Kejahatan seksual terhadap anak merupakan masalah global di mana anak-anak mengalami berbagai macam bentuk kekerasan seperti hukuman terhadap fisik, pemaksaan dalam pekerjaan yang berbahaya seperti pertambangan, sampah, seks komersial dan perdagangan narkoba serta terjadinya diskriminasi, perkawinan dini, dan pornografi. ${ }^{4}$

Pengakuan atas eksistensi anak sebagai subyek hak asasi manusia yang memiliki arti khusus, dapat dilihat dengan diratifikasinya Konvensi Hak Anak pada 20 November 1989 dan juga dalam Kode Etik Pariwisata. Konvensi hak anak memiliki suatu ikatan hukum bagi setiap negara yang ikut meratifikasinya. Konvensi hak anak juga membentuk suatu komite yang dikenal dengan sebutan CRC (Committee on the Rights of the Child) yang berfungsi untuk memonitor kemajuan yang dibuat oleh negara pihak terhadap kewajibannya menurut ketentuan yang tercantum dalam konvensi dan protokol operasionalnya. ${ }^{5}$ Dalam kode etik pariwisata, eksploitasi seksual yang dilakukan terhadap anak-anak sangat bertentangan dengan tujuan dasar dari pariwisata. Oleh sebab itu, eksploitasi seksual terhadap anak harus dilarang sekeraskerasnya serta diberikan sanksi yang tegas dan berat bagi para pelaku. Namun sampai saat ini kondisi tersebut belum teratasi. Hal ini

Irwanto, 2008, Menentang Pornografi dan Eksploitasi Seksual terhadap Anak, ECPAT, Jakarta, hlm.6.

Erica Harper, 2009, International Law and Standard Applicable in Natural Disaster Situation, PT. Grasindo, Jakarta, hlm. 204. terlihat dari adanya akses yang memudahkan kegiatan itu terjadi merupakan penyebab utamanya. Namun sampai saat ini kondisi tersebut belum teratasi. Hal ini terlihat dari adanya akses yang memudahkan kegiatan itu terjadi merupakan penyebab utamanya.

Pariwisata seksual anak merupakan salah satu bentuk dari kejahatan seksual yang timbul dari hasil suatu pergeseran nilai pariwisata dan merupakan suatu tindak kejahatan seksual pada anak. Para pelaku wisatawan seks anak dapat berasal dari negara lain yang biasa disebut sebagai wisatawan asing serta berasal dari dalam negeri yang disebut sebagai wisatawan domestik atau orang lokal yang melakukan perjalanan wisata di dalam negara mereka sendiri.

Permasalahannya adalah dengan adanya wisatawan asing maupun domistik yang berlibur maupun pada akhirnya menetap di suatu daerah yang membawa pengaruh negatif yaitu menggunakan jasa anak sebagai pemuas hasrat seksual yang saat ini lebih dikenal dengan pariwisata seks anak karena mayoritas menggunakan layanan atau akomodasi pariwisata di daerah wisata. Pengaruh tersebut mengakibatkan suatu perubahan sosial, dimana bisa mengarah pada perubahan yang tidak dikehendaki seperti contoh pergeseran nilai pariwisata. Pergeseran nilai merupakan masalah sosial pada zaman modern yang dianggap sebagai penyakit sosial, dan pada umumnya dikenal sebagai penyakit masyarakat. ${ }^{6}$ Dengan kata lain penyakit tersebut merupakan produk sampingan, atau merupakan konsekuensi yang tidak diharapkan dari system sosio-

Kartini Kartono, 2005, Patologi Sosial : Jilid 1, Raja Grafindo Persada, Jakarta, hlm.6. 
kultural zaman sekarang, dan berfungsi sebagai gejala sosial tersendiri.?

Resiko yang membahayakan masa depan anak juga dapat terjadi bilamana anak-anak terlibat ataupun dipaksa untuk masuk dalam industri seksual. Hal tersebut merupakan suatu tindak pelanggaran terhadap hak asasi anak.

Keterlibatan anak di dalam bisnis seks komerisal hampir terjadi disemua Negara dan belum ada penanganan secara serius dalam hal tersebut. Sebelum menindaklanjuti dalam upaya hukum, maka harus diketahui terlebih dahulu akar permasalahannya yaitu faktor yang mempengaruhi anak terlibat dalam pariwisata seks tersebut. Berdasarkan hal tersebut, penelitian yang dilakukan adalah penelitian yang berkaitan dengan "Pariwisata Seksual Anak : Upaya Perlindungan Anak Berkaitan Dengan Sex Child Tourism".

\subsection{Rumusan Masalah}

1. Apakah faktor penyebab teradinya pariwisata seksual anak?

2. Bagaimana upaya meningkatkan perlindungan hukum terhadap anak terhadap dampak negatif dari perkembangan pariwisata?

\subsection{Tujuan Penelitian}

\section{Tujuan Umum}

Untuk mengembangkan pengetahuan dibidang perlindungan anak dari bahaya kejahatan seksual khususnya pariwisata seksual anak yang

\section{Tujuan Khusus}

Untuk menganalisis dari pada faktor penyebab terjadinya pariwisata seksual anak serta perlindungan hukum terhadap anak yang menjadi korban dari pariwsisata seksual anak.

\section{Metode Penelitian}

Metode penelitian yang dilakukan adalah metode hukum normatif. Metode hukum normatif disebut juga sebagai penelitian hukum teoritis/ doktrinal dengan fokus kajian yang terletak pada inventarisasi hukum positif, asas-asas dan doktrin hukum, penemuan hukum dalam perkara in concreto, sistematik hukum, taraf sinkronisasi hukum, perbandingan hukum, dan sejarah hukum. ${ }^{8}$ Penelitian hukum normatif ini akan mengkaji dan menganalisis mengenai faktor penyebab terjadinya pariwisata seksual anak dan bentuk perlindungan hukum yang diberikan oleh negara pada anak yang menjadi korban. Jenis pendekatan yang digunakan dalam penelitian ini adalah pendekatan perundangundangan, serta pendekatan konsep dengan menggunakan teknik analisis bahan hukum berupa teknik analisis deskriptif yang bertujuan untuk membahas permasalahan sebagaimana sebelumnya telah diuraikan.

\section{HASIL DANPEMBAHASAN}

\subsection{Faktor penyebab teradinya pariwisata seksual anak di daerah pariwisata Bali}

Berikut ini ada beberapa faktor yang menjadi pendorong pendukung utama dalam hal terjadinya pariwisata seks anak ini, antara lain: ${ }^{9}$

Bambang Sunggono, 2009, Metodologi Penelitian Hukum, Raja Grafindo Persada, Jakarta, hlm.81-99.

John Paul Manik, 2011, Peran United Nations World Tourism Organization (Unwto) Dalam Program Pemberantasan Eksploitasi Seksual Anak Dalam Industry Pariwisata Di Brazil Tahun 2006-2012, Universitas Riau, Sumatera Utara, hlm.4. 


\subsubsection{Faktor Eksternal}

Dikatakan sebagai faktor utama terhadap terjadinya penyebab terjadinya pariwisata seks anak yang berawal dari adanya permintaan dari wisatawan baik asing maupun lokal yang diakibatkan dari banyaknya promosi yang dilakukan oleh para penyedia jasa prostitusi atau prostitution supplier. Penyedia jasa prostitusi tersebut biasanya menawarkan atau mengajak korban dengan cara memberikan bujukan dengan cara yang bergammulai memberikan pekerjaan dan uang dalam waktu yang singkat, serta bujukan lainnya kepada anak-anak agar mau terjun ke dalam dunia prostitusi. Di samping itu dapat juga dilakukan dengan modus penipuan berkedok penyalur atau agen tenaga kerja dengan memberi harapan atau janji mendapatkan pekerjaan yang lebih baik. ${ }^{10}$ Berbagai macam promosi yang dilakukan para jasa penyalur prostitusi tersebut mengatakan bahwa anakanak yang terlibat dalam hal ini lebih aman dari jangkitan penyakit menular seksual dikarenakan pengalaman anak-anak tersebut tidak sebanding dengan orang dewasa yang terlibat di dunia prostitusi. Wisatawan akan lebih tertarik dari adanya promosi ini dengan memillih anak-anak daripada orangorang dewasa dikarenakan alasan keamanan kesehatan serta menjadikan sebuah trend baru di dunia prostitusi terhadap adanya pariwisata seksual anak. Pemasaran prostitusi ini ditunjang pula dengan perkembangan teknologi yaitu melaui fasilitas internet atau online dimana pemasok jasa prostitusi anak dapat memasang informasi sehingga memudahkan pelaku seks dalam hal

Victor Malarek, 2008, Menyibak Perdagangan Seks Dunia, Serambi Ilmu Semesta, Jakarta, hlm.27. transaksi. ${ }^{11}$ Trend dapat merubah gaya hidup yang sangat mempengaruhi perubahan sosial seperti dengan adanya pariwisata seksual anak ini yang pada nantinya akan menarik banyak minat para wisatawan seksual anak.

\subsubsection{Faktor Internal}

Faktor internal dapat dikatakan sebagai faktor sekunder terhadap terjadinya pariwisata seks anak karena faktor ini ada disebabkan adanya factor utama atau primer yaitu adanya permintaan dari wisatawan. Permasalahan ekonomi merupakan masalah yang mengakibatkan anak yang menjadi korban pariwisata seksual dikarenakan tidak terpenuhinya kebutuhannya secara keuangan atau finansial. Kebutuhan primer yang belum terpenuhi tersebut seperti kurangnya perhatian terhadap pendidikan yang mengakibatkan anak-rendahnya kemampuan intelektual sehingga dengan mudah masuk dan terjerumus dalam dunia prostitusi yang dominan menjanjikan terpenuhinya kebutuhan finansial bagi anak-anak tersebut sepertikeinginan dalam hal kepemilikan suatu barang mewah sehingga mereka memiliki pemikiran untuk menghasilkan uang dengan cara yang cukup singkat dan juga dengan mudah. Permasalahan selanjutnya adalah dalam lingkungan keluarga (permasalahan keluarga) yang berakibat kurangnya perhatianyang diberikan kepada anak dari orangtuanya. Prostitusi dapat dikatakan sebagai sebuah jaringan yang didukung oleh berbagai macam teknologi oleh sebab itu akan dengan cepat bergerak dan membuat pengaruh negative pada setiap anak yang telah terjerumus di dalamnya.

11 Jim Walter and Patricia H. Davis, 2011, Human Trafficking, Sex Tourism, and Child Exploitation on the Southern Border, Southern Methodist University, hlm.11. 
Namun faktor yang paling dominan yang saat ini dijumpai adalah faktor ekonomi yang penyebab utamanya adalah kemiskinan. Berdasarkan hasil wawancara dengan Kompol Putu Nariasih, selain faktor kemiskinan ada faktor lainnya yang mendukung timbulnya eksploitasi seksual pada anak yaitu keinginan dari anak sendiri dikarena tuntutan perkembangan zaman. Maksud daripada tuntuan perkembangan zaman adalah dapat dilihat dari gaya hidup modern yang lebih cenderung hedonis yang pada saat ini dialami oleh anak-anak. Pemenuhan kebutuhan hidup yang sangat terbatas mendorong anak tersebut melakukan berbagai macam cara agar dapat mengikuti perkembangan zaman yang sarat akan unsur modern dan cenderung hedonis, karena orang tua yang berpengahsilan minim, menyebabkan anak-anak tersebut mencari jalan pintas yang negatif yaitu dengan menjual dirinya ke laki-laki hidung belang.

Berdasarkan hasil wawancara dari seorang anak yang berusia 18 Tahun dan bekerja pada salah satu Spa yang menyediakan sensasi seksual dengan nama yang disamarkan, sebut saja Moza. memiliki pekerjaan sebagai terapis dari sebuah Spa sensasi merupakan suatu hal yang belum pernah dibayangkan olehnya, dan yang melatarbelakangianaktersebutbekerjaadalah karena ajakan seorang teman dan juga hanya sebatas mengikutinyadan baru dijalankan selama 1 bulan belakangan. Teman yang mengajak anak tersebut merupakan seorang mucikari dari Spa tempatnya bekerja, sebut saja Jeje. Menyenangkan hati orang tua merupakan salah satu tujuan Moza bekerja agar menghasilkan uang. Di sisi lain, orang tua Moza tidak mengetahui pekerjaan seperti apa yang digeluti oleh anaknya. Berdasarkan hasil wawancara dari mucikari Spa itu, mengenai izin yang diajukan Spa tersebut adalah didaftarkan sebagai Salon. Hal ini dikarenakan apabila didafatarkan dengan kondisi Spa yang dijalankan adalah Spa yang menawarkan sensasi maka tidak akan diizinkan untuk beroperasi karena sudah jelas melanggar uandang-undang.

\subsection{Upaya meningkatkan perlindungan hukum terhadap anak dari perkembangan pariwisata di Bali}

Para penegak hukum sudah seharusnya memberikan perhatian yang lebih untuk perlindungan hukum bagi masyarakat. Berdasarkan undang-undang perlindungan anak No. 35 Tahun 2014 kewajiban memberikan perlindungan kepada anak didasarkan pada asas non-dikriminasi, asas kepentingan yang terbaik untuk anak, asas hak untuk hidup, kelangsungan hidup, dan perkembangan, serta asas penghargaan terhadap pandangan atau pendapat anak. ${ }^{12}$ penegakanhukumsebagaiupayaperlindungan terhadap anak dalam hal tertentu juga dapat dilakukan oleh pihak swasta ataupun masyarakat guna mewujudkan ide ataupun konsep dan juga kaidah hukum, baik tertulis maupun tidak yang bersifat normatif yang terwujud dalam fakta maupun kasus dalam kehidupan masyarakat. ${ }^{13}$

\subsubsection{Upaya Perlindungan Hukum Preventif}

Philipus Hadjon memberikan konsep tentang teori perlindungan hukum

Rika Saraswati, 2009, Hukum Perlindungan Anak Di Indonesia, Citra Aditya Bakti, Bandung, hlm.25-26.

3 Munir Fuady, 2007, Sosiologi Hukum Kontemporer, Interaksi Hukum, Kekuasaan, dan Masyarakat, PT. Citra Aditya Bakti, Bandung, hlm.107. 
yakni, perlindungan hukum preventif dan perlindungan hukum represif. Maka dari itu upaya yang dilakukan dalam mencegah terjadinya eksploitasi seksual yang berupap ariwisata seks terhadap anak adalah berupa:

1. Pengaturan dalam sudut pandang normatif yaitu berupa Peraturan Perundang-Undangan,

Pemberian sanksi yang berat terhadap pelaku merupakan hal yang harus diperhatikan dalam sudut pandang perundang-undangan. Dalam pemberian sanksi yang berat tersebut harus diperhatikan juga pada motif pelaku, tujuan pelaku melakukan tindak pidana, cara pelaku melakukan tindak pidana dan motif korban.

2. Memaksimalkan Kinerja Lembaga Perlindungan Anak

Lembaga ini perlu didukung setidaknya oleh pekerja sosial, psikolog, ahli hukum dan dokter dengan maksud agar lembaga ini dapat mencapai tujuan yang diinginkan dengan baik.

\subsubsection{Upaya Perlindungan \\ Represif}

Hukum

Dilakukan dengan pemberian restitusi serta kompensasi dengan tujuan pengembalian kerugian yang dialami oleh korban baik fisik ataupun psikis. Selain itu dapat juga dengan diadakannya rehabilitasi dan juga pelayanan medis terhadap korban.

Selain upaya hukum di atas, selaku Kanit I Subdit IV Ni Nyoman Sukerni memaparkan mengenai upayayang dilakukan polri untuk melindungi anak dari eksploitasi seksual, antara lain:

1. Membangununit pelayanan perempuan anak (uppa) yang akan menangani kasus yangg menimpa anak, merujuk ke Rumah Sakit, Shelter, Psikolog di seluruh kepolisian indonesia (Mabes Polri-Polres)

2. Meningkatkan kemampuan personil Polri (khususnya polwan dan polri yang diarahkan untuk menangani hal-hal yang terkait perempuan dan anak yang sensitif gender dengan menggunakan fasilitas ruang pelayanan khusus)

3. Meningkatkan kerjasama dan koordinasi dengan instansi terkait dan lembaga swadaya masyarakat terkait

4. Melakukan sosialisasi bekerjasama dengan insan pers baik melalui media cetak dan elektronik

5. Kerjasama dengan kepolisian asing melalui Interpol dan SLO yang ada di indonesia.

Peraturan hukum mengenai perlindungan anak pada awal mulanya sudah diatur melalui Undang-Undang No. 23 Tahun 2002, namun karena di dalamnya tidak tercantum cukup kuat mengenai kepentingan pelaku, maka direvisi dengan peraturan baru yaitu Undang-Undang No. 35 Tahun 2014. Disini saatnya para penegak hukum untuk lebih memperhatikan implementasi dari undang-undang ini.

Selain upaya yang telah dilakuakan oleh negara yang masuk ke dalam instrument nasional, organisasi internasional juga memiliki peranan yang penting dalam melakukan upaya perlindungan. Organisasi Internasional merupakan pola kerjasama yang melintasi batas-batas negara, yang didasari struktur organisasi yang jelas dan lengkap serta diharapkan atau diproyeksikan untuk berlangsung serta melaksanakan fungsinya secara berkesinambungan dan melembaga guna mengusahakan tercapainya tujuan-tujuan yang diperlukan serta 
disepakati bersama, baik antara pemerintah dengan pemerintah maupun antara sesama kelompok non-pemerintah pada negara yang berbeda. ${ }^{14}$ Oleh karena itu, peranan daripada organisasi internatsioal adalah:

1. Sebagai tempat menggalang suatu kerjasama dan untuk mencegah serta dalam hal pengurangan intensitas daripada suatu konflik.

2. Sebagai wadah untuk bermusyawarah serta menghasilkan keputusan yang menguntungkan bagikepentingan bersama.

3. Sebagai lembaga indipenden dalam hal pelaksanaan suatu kegiatan sosial kemasyarakatan.

\section{SIMPULAN \& SARAN}

\subsection{Simpulan}

1. Faktor dominan yang menjadi latar belakang dari timbulya pariwisata seksual anak terdiri dari faktor ekstern dan intern. Faktor ekstern adalah perkembangan zaman untuk mengikuti lifestyle dan juga memenuhi kebutuhan tersier. Faktor intern adalah permasalahan utamanya yaitu faktor perekonomian keluarga.

2. Upaya-upaya perlindungan terhadap hak anak masih harus terus dirancang dan harus ada penguatan birokrasi di Indonesia sehingga nasib anak-anak bisa lebih terlindungi. Upaya tersebut harus lebih mengupayakan agar hak anak lebih dilindungi agar tidak terjadi peningkatan tindak pidana eksploitasi seksual anak, apabila sudah terjadi maka perlindungan anak sebagai korban harus lebih diperhatikan hingga anak tersebut dapat beraktifitas normal kembali seperti upaya terhadap pengawasan terhadap anak-anak, upaya pencegahan agar anak terhindar dari bahaya eksploitasi seksual, upaya perawatan apabila anak sudah menjadi korban, dan upaya rehabilitasi.

\subsection{Saran}

1. Pemerintah bersama dengan para penegak hukum harus melakukan realisasi secara bersungguh-sungguh dan melakukan penegakan birokrasi atas peraturan-peraturan yang telah ada serta membuat undang-undang dan perjanjian baru jika perlu yang lebih tegas dan mengikat. Hal tersebut dapat dilakukan dengan pembenahan dari segi fasilitas yang ada untuk menaungi perlindungan hak terhadap anak maupun pembenahan dari penegakan hukum dari sisi kualitas dan kuantitasnya

2. Pengawasan yang lebih diperketat terhadap tempat yang terindikasi beresiko tinggi terjadinya eksploitasi seksual anak serta memperketat kekuatan hukum di daerah yang wisatanya sedang berkembang, Pemerintah bersama para penegak hukum harus lebih gencar dalam hal edukasi melalui sosialisasi kepada anak, remaja dan orang tua tentang bahaya dari eksploitasi seksual karena semakin banyak yang mengetahui maka akan lebih gampang untuk upaya pencegahan.

14 Teuku May Rudy, 2009, Administrasi \& Organisasi Internasional, Refika Aditama, Bandung, hlm.3. 


\section{DAFTAR PUSTAKA}

Fuady, Munir., 2007, Sosiologi Hukum Kontemporer, Interaksi Hukum, Kekuasaan, dan Masyarakat, PT. Citra Aditya Bakti, Bandung.

Harper, Erika., 2009, International Law and Standard Applicable in Natural Disaster Situation, PT. Grasindo, Jakarta.

Irwanto, 2008, Menentang Pornografi dan Eksploitasi Seksual terhadap Anak, ECPAT, Jakarta.

Kartono, Kartini., 2005, Patologi Sosial : Jilid 1, Raja Grafindo Persada, Jakarta.

Laheri, Eva., 2015, Tanggung Jawab Negara Terhadap Kerugian Wisatawan Berkaitan Dengan Pelanggaran Hak Berwisata Sebagai Bagian Dari Hak Asasi Manusi, Jurnal Magister Hukum Udayana Vol.8 No.1 Tahun 2015, Magister Hukum Universitas Udayana, Denpasar.

Malarek, Victor., 2008, Menyibak Perdagangan Seks Dunia, Serambi Ilmu Semesta, Jakarta.

Manik, John Paul., 2011, Peran United Nations World Tourism Organization (Unwto) Dalam Program Pemberantasan Eksploitasi Seksual Anak Dalam Industry Pariwisata Di Brazil Tahun 2006-2012, Universitas Riau, Sumatera Utara.

Prabhata, Iriandika., 2015, Meningkatkan Pariwisata Bali Melalui Kepastian Penegakan Hukum atas Pelanggaran Kawasan Tanpa Rokok Dalam Peraturan Daerah Propinsi Bali No. 10 Tahun 2011, Jurnal Magister
Hukum Udayana, Vol.8 No.1 Tahun 2015, Magister Hukum Universitas Udayana, Denpasar.

Saraswati, Rika., 2009, Hukum Perlindungan Anak Di Indonesia, Citra Aditya Bakti, Bandung.

Sunggono, Bambang., 2009, Metodologi Penelitian Hukum, PT Raja Grafindo Persada, Jakarta.

Teuku May Rudy, 2009, Administrasi \& Organisasi Internasional, Refika Aditama, Bandung.

Walter Walters, Jim and Davis, Patricia H., 2011, Human Trafficking, Sex Tourism, and Child Exploitation on the Southern Border, Journal of Applied Research on Children: Informing Policy for Children at Risk: Vol. 2: Iss. 1, Article 6 , Southern Methodist University. 